Modern Asian Studies 56, I (2022) pp. I42-I75. C The Author(s), 2021. Published by Cambridge University Press. This is an Open Access article, distributed under the terms of the Creative Commons Attribution-NonCommercial-NoDerivatives licence (http:// creativecommons.org/licenses/by-nc-nd/4.o/), which permits non-commercial re-use, distribution, and reproduction in any medium, provided the original work is unaltered and is properly cited. The written permission of Cambridge University Press must be obtained for commercial re-use or in order to create a derivative work.

doi:I0.I017/Soo26749X2000058X First published online 29 March 202I

\title{
Informality, Temporariness, and the Production of Illegitimate Geographies: The rise of a Muslim sub-city in Ahmedabad, India (I97os-200os)
}

\author{
TOMMASO BOBBIO
}

\author{
Dipartimento di Culture, Politica e Società, Università di Torino \\ Email: Tommaso.bobbio@unito.it
}

\begin{abstract}
In recent debates in the field of urban studies, issues of informality, marginal settlements, and extreme poverty have often been analysed in relation to the dynamics that transformed spatial and social balances with respect to neo-liberal economic policies. The restructuring of spaces, infrastructure, and economies that marked the success of changing paradigms of urban planning since the Ig9os has been widely seen to be responsible for the extensive marginalization of the most vulnerable strata of society. In order to understand the emergence of areas considered informal - or illegitimate - this article aims to question the very validity of categories such as 'informality' when applied to analysing the transition from medium-sized urban centres to 'mega-cities' (a label that, in itself, blindly recalls the allure of modernization, technology, and development). ${ }^{1}$ It does so by adopting a longer term perspective in analysing the evolution of a municipal housing project for the resettlement of slumdwellers in Ahmedabad, India, in 1978, which, in the span of four decades, turned into a substandard informal settlement and then into a 'Muslim city' called Juhapura. Widely known in India as the 'biggest ghetto in South Asia', this area is an observatory for reconsidering the significance of concepts such as informality, illegality, temporariness, and people's legitimacy as citizens.
\end{abstract}

${ }^{1}$ Gayatri Chakravorty Spivak, 'Megacity', Grey Room, no. I, Fall 200o, pp. 8-25. 


\section{Introduction: communal violence and the search for a 'homely' place in the city}

It was during I986. My kids were very small and lot of riots used to happen. The military used to come inside and used to harass us. We use to go here and there. Then I said to myself that the kids are small so anybody at my parent's place can handle them, but when they grow up it does not look good to stay in either families, therefore we came here.

Then here it was good for us. Over here there is no worry about riots. Over there police use to harass us a lot. They use to enter in the house in case of more riots. Then where do we run. Once, when intense riot happened, I kept my house open and ran away. That time my kids were very small, 4 years, so we went to my mother's place. Also opposite to my mother's place, in Khadia and other places, lot of riots use to take place.

I told my mother that I cannot stay over here and so from there I went to my sister's place in Shah-Alam. Over there I stayed for few days and then I came back home. Obviously we have to come back home because how long can we stay at someone's place? After that when time passed we left that home and moved here [to Shanklit Nagar]. ${ }^{2}$

I came here in I985. I left the place. I was married and so had to leave the society. At first, I stayed on rent and then I purchased my own house.

Marriage was the only reason why we moved to Juhapura. As my brother also got married, we all needed more space. Therefore, I came here. But still we have a good relation and we visit each other's home. We chose this area because at that time in the city the prices were more and over here they were less. At that time over here we use to get a house in around Rs 25,000 to Rs 26,000 while in the city they were Rs 50,000 and up to Rs 65,000.

In the beginning, I stayed on rent. My house was there. There was a municipal bus stand on the opposite side near the water tank. We could see from there whoever came in or went out. But now so many constructions have come up that nothing is visible. When we came to Juhapura, it was like a jungle, while now it has lot of population. Previously there was dark outside but now even at II:Oo or I2:00 in the night you can go out.

\footnotetext{
${ }^{2}$ Interview IV, 6I-year-old tailor, I July 2008, formerly living in Shahpur (Old City), then in Shanklit Nagar from the beginning of the r9gos. All interviews were undertaken in Gujarati during I4 months of fieldwork (2007-2008) and subsequent shorter periods in Ahmedabad between 2007 and 2016. The criteria for selecting respondents was mainly their age - preferably above 65 - and familiarity with the city, so as to be able to follow life trajectories spanning several decades that included many house changes and internal movement. For privacy reasons, the names of the interviewees have been omitted and each interview is referenced with a roman number, the age and occupation of the respondent, and the date it took place. All records and transcripts are available in the author's personal archive.
} 
Between Juhapura and the city there was nothing. Right now more shopping centres and markets have come up and also the population has increased so everything is available on roads. ${ }^{3}$

The two voices that open this article include some of the most common elements that recur in the narratives of older residents of Juhapura, a Muslim sub-city of about 500,000 inhabitants located at the southwestern edge of Ahmedabad in the Indian state of Gujarat (see Map I). It contends with Mumbai's neighbourhood of Mumbra for the title of 'the biggest ghetto in South Asia', thanks to a successful journalistic description which has now largely been adopted by its residents; it is also known as the more aggressively labelled 'mini-Pakistan' by sympathizers of right-wing Hindu extremist groups. Juhapura has often been taken as an example of the extreme economic, social, and spatial marginalization in which Muslim citizens are frequently forced to live nowadays in Indian cities. ${ }^{4}$ From a different angle, Juhapura today can be seen as the spatial outcome of the rise of Hindu fundamentalist associations that have been centre stage of the country's political and social life since the late ig8os. ${ }^{5}$

Yet, as the two quotations suggest, communal violence and widespread religious discrimination do not provide sufficient explanation for the dynamics that led to what would become one of the biggest segregated neighbourhoods in Indian megalopolises. Both these elements - violence and religious discrimination - are deeply inscribed in the memories of the residents of Juhapura, as well as in those of Ahmedabad's non-Muslim residents who identify Juhapura as the locus and the source of instability and insecurity for the city. Those two memories also show that communal violence, riots, and cultural and political intolerance comprise a background against which one can observe life trajectories that transcend religious identity and which are made up of choices and constraints - from the search for a safe and affordable place to live in the city to the constant threat of being evicted - and more often than not marked by extreme poverty and deprivation. The spaces

\footnotetext{
${ }^{3}$ Interview IX, 62-year-old rickshaw driver (former employee at the Gujarat State Transport Corporation), I6 July 2008, Shanklit Nagar.

${ }^{4}$ Rajinder Sachar, Social, Economic and Educational Status of the Muslim Community of India: A Report (New Delhi: Prime Minister's High Level Committee, Cabinet Secretariat, Government of India, 2006), pp. I4 ff; $242 \mathrm{ff}$.

${ }^{5}$ Ashis Nandy, Shikha Trivedy, Shail Mayaram and Achyut Yagnik, Creating a Nationality: The Ramjanmabhumi Movement and Fear of the Self (Delhi; Oxford: Oxford University Press, I995; ist edn), pp. IIO-I23.
} 


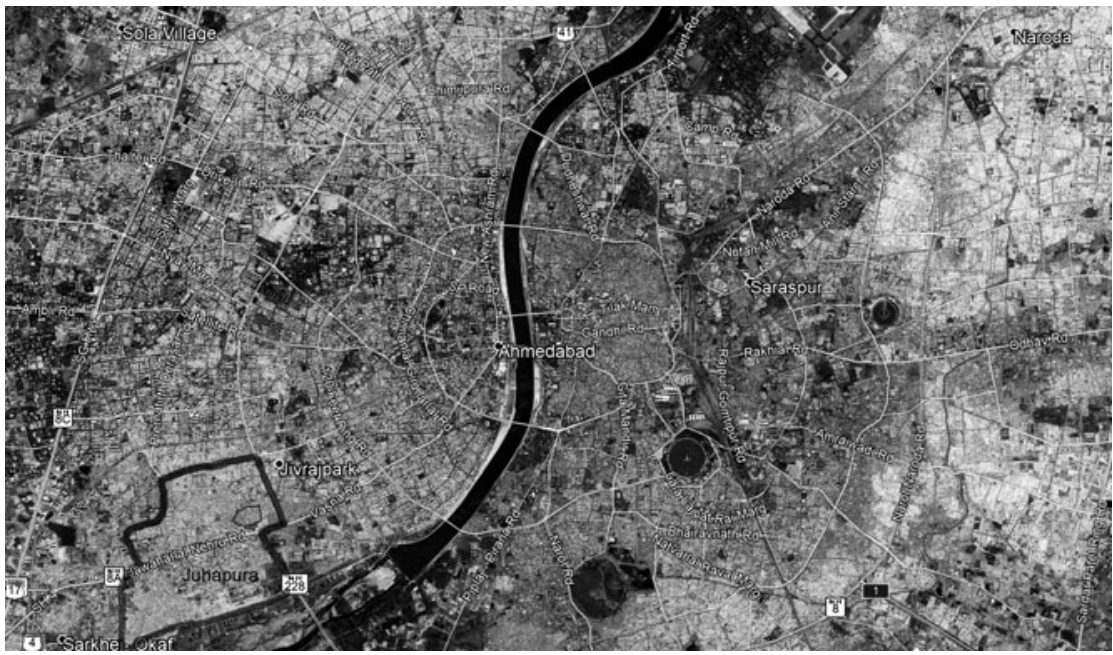

Map I. Aerial view of Ahmedabad city. Highlighted in the southwestern corner is the border of the Muslim sub-city of Juhapura and, within it, the area of the first settlement of Shanklit Nagar. Source: This map is derived from Google Earth; the boundaries of Juhapura neighbourhood were drawn by the author from local maps, and from surveys conducted and information collected by him.

in which these people moved and lived their lives have blurred boundaries that often elude the control of public administrations. For this reason, they are considered illegal, temporary, or illegitimate, something that lies outside the development trajectory of the city.

This article thus proposes to read through the multi-dimensional history of Juhapura - as a progressive example of a municipal relocation project, a decentralized and degraded neighbourhood, and a symbol of Muslim annihilation as citizens in today's India - to see how the limbo of informality has become instrumental in disempowering large sectors of urban society. It does so for a diachronic perspective that allows us to call into question epistemological frameworks in which urban development is implicitly inscribed in a trajectory of linear growth, and whose steps are somehow seen as inevitable and delinked from their spatial and historical dimension. Looking at the ways in which a place like Juhapura grew over time, was selected by an increasingly large number of people as an affordable or safe destination to live, and underwent a process of communal identification leads us to explore the fickle separation between legality and illegality, formality and informality, to better understand such categorizations as 'flexible' and 'contingent' in the milieu of power relationships, tensions, and constraints that shape the urban space over 
time. ${ }^{6}$ The idea of a ghetto needs to be nuanced, as Juhapura is better understood as a 'residual space' born as a 'by-product' of contested spaces, something that encompasses the characteristics of a slum (as a space of unrecognized and uncertain land tenure) and of a refugee camp (as a space of exception separated from the cityscape). ${ }^{7}$ Yet, being a residual space does not qualify Juhapura necessarily or exclusively as economically marginal and backward: as the various phases of its growth show, it gradually became a place where the Muslim middle classes sought to move when communal tensions rose to an unbearable level. As Mahadevia rightly observed in the wake of the dreadful anti-Muslim pogroms that shook the city in 2002, Juhapura most of all can be described as a sub-city. ${ }^{8}$ In response to Mahadevia, Jaffrelot and Thomas contested that in Juhapura 'we do not find at all "every thing that a new city requires" there: the state is missing. ${ }^{9}$ These two, apparently contrasting, perspectives only confirm that patterns of segregation and informalization need to be seen as part of a process of continuous redefinition of geographies of power and relationship in the city. In this regard, the idea of a sub-city allows us to take into account the crucial issue of choice in a more flexible and nuanced way. ${ }^{10}$ If the 'ghetto' as a

${ }^{6}$ Don Mitchell, 'The annihilation of space by law: the roots and implications of anti-homeless laws in the United States', Antipode, vol. 29, no. 3, I997, pp. 303-335; Doreen Massey, 'Imagining globalization: power-geometries of time-space', in Global Futures: Migration, Environment and Globalization, (eds) A. Brah, M. Hickman and M. Mac an Ghaill (New York, NY: St Martin's Press, 1999), pp. 27-44.

${ }^{7}$ The idea of residual space is here drawn from Noura Alkhalili, Muna Dajani and Daniela DeLeo, 'Shifting realities: dislocating Palestinian Jerusalemites from the capital to the edge', International fournal of Housing Policy, vol. I4, no. 3, 2014, p. 259, while the comparison with refugee camps, which actually fits the latest part of the history of Juhapura (post-2002 pogroms), is here taken from Romola Sanyal, 'A no-camp policy: interrogating informal settlements in Lebanon', Geoforum, no. 84, 20I7, p. I20.

${ }^{8}$ Darshini Mahadevia, 'A city with many borders - beyond ghettoisation in Ahmedabad', in Indian Cities in Transition, (ed.) A. Shaw (Hyderabad: Orient Longman, 2007).

${ }^{9}$ Christophe Jaffrelot and Charlotte Thomas, 'Facing ghettoisation in a riot city. Old Ahmedabad and Juhapura between victimisation and self-help', in Muslims in Indian Cities: Trajectories of Marginalisation, (eds) Laurent Gayer and Christophe Jaffrelot (London: Hurst and Co., 2012), p. 7r. Raphael Susewind, in a response to Jaffrelot and Thomas, argued that the level of segregation depends not only on residential patterns but also on people's 'view' of implicit boundaries in the urban territory. Raphael Susewind, 'Muslims in Indian cities: degrees of segregation and the elusive ghetto', Environment and Planning, vol. 49, no. 6, 2017, pp. I286-1307.

${ }^{10}$ On this, see Ghazala Jamil, Accumulation by Segregation: Muslim Localities in Delhi (New Delhi: Oxford University Press, 2017); Radhika Gupta, 'There must be some way out of 
conceptualization always implies a level of coercion, looking at Juhapura as a sub-city stuck in the grey zone of informality allows us to evaluate how people constantly try to enact strategies (and often fail) in order to exert some choice, while the virtual absence of the state results in more constraints.

Practically all works on Juhapura focus on the events that followed the 2002 violence. $^{11}$ In contrast, this article argues that each phase of the history of this large portion of Ahmedabad - from its origin as a municipal relocation settlement in the late 1970 s to hosting the majority of the people displaced by the 2002 anti-Muslim pogrom - shows a stratification of processes and meanings that made this area contested alongside repeated and extensive communal tensions in the city. How did such a place become a segregated Muslim neighbourhood? One can see how the state has been very much present both as an active subject in shaping Juhapura as it is today and as an ideal counterpart in the eyes of its residents, who are afraid of its arbitrariness but at the same time entrust it with their aspirations to progress and enjoy economic development. On the other hand, issues relating to slum relocation and the availability of affordable housing, which made Juhapura attractive for slumdwellers and casual labourers in the I980s, need to be read against the background of industrial dismissions and political unrest that paved the way for Ahmedabad to become a 'laboratory of Hindutva' towards the end of that decade. ${ }^{12}$ The convergence of Hindu revivalist propaganda and a neo-liberal economic agenda into a uniform political platform can be seen as the main

here: beyond a spatial conception of Muslim ghettoization in Mumbai?', Ethnography, vol. I3, no. 3, pp. $35^{2-}-370$.

${ }^{11}$ The works of Ipsita Chatterjee and Rubina Jasani are among those which offer the most interesting insights. See, for instance, I. Chatterjee, 'Social conflict and the neo-liberal city: a case of Hindu-Muslim violence in India', Transactions of the Institute of British Geographers, vol. 34, no. 2, 2009, pp. I43-16o; I. Chatterjee, 'How are they othered? Globalisation, identity and violence in an Indian city', The Geographical Fournal, vol. I73, no. 2, 2012, pp. I34-I46; R. Jasani, 'Violence, reconstruction and Islamic reformstories from the Muslim "ghetto", Modern Asian Studies, vol. 42, no. 2/3, 2008, pp. 43 I456; Neera Chandhoke, Praveen Priyadarshi, Silky Tyagi and Neha Khanna, 'The displaced of Ahmedabad', Economic and Political Weekly, vol. 42, no. 43, 27 October-2 November 2007, pp. IO-I4.

${ }^{12}$ Howard Spodek, 'In the Hindutva laboratory: pogroms and politics in Gujarat, 2002', Modern Asian Studies, vol. 44, no. 2, 2010, pp. 349-399. Ornit Shani highlighted how the rise of Hindutva during the ig8os meant a disruption of the solidarity between Muslim and Dalit groups in the industrial areas, with the integration of the latter into a pretended homogeneous Hindu fold: O. Shani, Communalism, Caste and Hindu Nationalism: The Violence in Gujarat (Cambridge: Cambridge University Press, 2007). 
terrain with which Hindutva forces experimented in Ahmedabad: one of the most visible outcomes has been a progressive communalization of spaces, such as former industrial neighbourhoods where Dalits and Muslims used to live side by side. ${ }^{13}$ The emergence of religious or caste identities as elements that defined residential patterns, along with the consolidation of urban planning policies that created a regime of 'financial apartheid', represent the background against which the present analysis is developed. ${ }^{14}$

This article is divided into five parts. In the first, I propose that a historical reading of the development of a particular neighbourhood such as Juhapura allows us to engage with dominant theoretical frameworks about informality and poverty within the frame of the extraordinary rates of urbanization in twenty-first century India. Following from this point, in the second section I argue that in the language of urban administrators, which has been embraced by the middle classes in India, discourses on urban poverty tended to 'place the blame' on the behaviour of the urban poor rather than on structural and infrastructural deficiencies. ${ }^{15}$ This contributed to shape an understanding of issues relating to housing, sanitation, and work through language that delegitimized the slumdwellers as citizens and which, over time, paved the way for a further level of discrimination on grounds of religious or caste belonging. The third section brings in the

${ }^{13}$ Dyotana Banerjee and Mona G. Mehta, 'Caste and capital in the remaking of Ahmedabad', Contemporary South Asia, vol. 25, no. 2, 2017, pp. I82-195.

${ }^{14}$ Arjun Appadurai, 'Spectral housing and urban cleansing: notes on millennial Mumbai', Public Culture, vol. I2, no. 3, 2000, pp. 627-65I.

${ }^{15}$ Although it is difficult to quantify the number of the extremely poor in the city, it must be noted that, from the I99os, a progressive deregulation of the labour market determined a steep increase in the number of casual labourers, with a decrease in job security and wages among the lower sectors of society. For instance, the number of slumdwellers in Ahmedabad doubled in the period I99I-200I, from 430,955 (I4.5 per cent of the total population) in I991 to 907,662 (25.7 per cent) in 200I: Census of India $200 I$ (Government of India, Ministry of Home Affairs, 200I), pp. $344 \mathrm{ff}$. When using the definition of 'urban poor' in this article, I am therefore referring to a milieu of people who live at the margins of the urban economy, mostly engaged in casual labour, and striving to find a place in the city in those areas that urban authorities often consider 'informal'. The idea of placing the blame is borrowed from Paul Brass's paramount work on the production of communal riots, but applies just as well to a widespread hostility towards urban poverty. 'Blame displacement' is thus a process that 'does not isolate effectively those most responsible for the production of violence, but diffuses blame widely, blurring responsibility, and thereby contributing to the perpetuation of violent productions in future': Paul Brass, The Production of Hindu-Muslim Violence in Contemporary India (New Delhi: Oxford University Press, 2003), p. 15. 
empirical case of Ahmedabad, discussing the context in which the first settlement in the area of Juhapura emerged towards the end of the I970s. In that decade, institutional reactions to uncontrolled urban growth crystallized definitions of zoning and brought more peripheral areas within town planning schemes, thus reducing the possibility for the most vulnerable sectors of society to move across spaces to find suitable places to settle and work. The next section illustrates the trajectory of Juhapura from being an example of municipal authorities' efforts to resettle - and 'formalize' - dwellers of a central slum of the city, to becoming the epitome of the spatial consequences of decades of anti-Muslim rhetoric and politics, in the aftermath of the bloodshed that turned the city and the whole state of Gujarat upside down for months in the spring of 2002. In the concluding section, I make the point that the emergence of extremely segregated spaces can be better understood if they are seen in all their complexity, alongside all the contradictions of processes in which tensions produced by development policies, conceived with precise modalities, timing, and limits, force people to bargain for their existence in unpredictable, often unwanted, ways.

In order to unpack the pretended homogeneity and stability of certain categories over time, this article relies on two different sets of historical sources. Through the analysis of reports and policy guidelines on slums and informal settlements issued by central, state, and municipal bodies, it deals first with the creation of a public discourse and a shared culture linking informality, illegality, and temporariness in post-colonial urban India. The effects of such discourses in terms of policies of urban development, of popular perceptions about the city and its life, as well as of concrete access to services and infrastructure are then seen through the lens of the memories of older slumdwellers from both Shanklit Nagar/Juhapura and the nearby slum of Vasna. The oral sources used for this article consist of 33 open interviews with slumdwellers and several further conversations with selected informants, former officers of the Planning Department of the Ahmedabad Municipal Corporation, and social workers. ${ }^{16}$ Borrowing from the

\footnotetext{
${ }^{16}$ When I began collecting memories and surveying some of the slums of Ahmedabad in 2008, I was searching mainly for the intricate set of sociocultural and spatial dynamics that contribute to maintaining a state of routine violence in the city, while trying to expand this notion beyond the purely political meaning that historian Gyanendra Pandey attributes to it: see G. Pandey, Routine Violence: Nations, Fragments, Histories (Stanford, CA: Stanford University Press, 2006). The idea for this article was born several years and
} 
methodology of narrative enquiry in order to explore and understand personal experience within its wider social context, the reading of individual narratives makes space for cultural, social, and institutional aspects of personal lives. ${ }^{17}$ In this way, memories of older slumdwellers directly challenge policies of urban development, allowing us to scrutinize an idea of citizenship by looking at the creation of the conditions for accessing rights rather than their formal recognition. ${ }^{18}$ Moreover, issues raised in these collected memories invite us to see citizenship as a cultural fact, as the practice of belonging to and participating in the state. The plurality and coexistence of different spaces may appear as a 'cacophony', more than a 'choral singing', but it is through this cacophony that the basis for mutual recognition and cultural reciprocity are posed. ${ }^{19}$ Navigating through selections and omissions in people's accounts provides an interesting angle from which to investigate the processes that led to the emergence of collective or shared memories that encompass recurrent themes, such as violence and religious discrimination, but also the expansion of the urbanized territory or the experience of continual internal migrations or sharing extreme living conditions. ${ }^{20}$ The selective process in the consolidation of shared memories also reveals how these are 'mediated phenomena' in which, for instance, public discourses regarding the city's development and progress become part of the personal accounts of ordinary people taking part in the act of recollecting decades of living on the fringes of the city. ${ }^{21}$ But the text of collective memory always contains 'leaks': by

periods of fieldwork later, after rereading the memories I had collected that recounted the experiences of marginalized people who had endured decades of development policies, which had always been aimed at keeping them at the bottom of urban society and at the fringes of the urban space.

${ }^{17}$ Jean Clandinin, Engaging in Narrative Inquiry (Walnut Creek, CA: Left Coast Press, 2013).

${ }^{18}$ Lynn Staeheli, 'Cities and citizenship', Urban Geography, vol. 24, no. 2, 2003, pp. 97I02; Sharit K. Bhowmik, 'The politics of urban space in Mumbai. "Citizens" versus the urban poor', in Contested Transformations. Changing Economies and Identities in Contemporary India, (eds) M. E. John, P. K. Jha and S. Jodhka (New Delhi: Tulika Books, 20o6).

${ }^{19}$ Lion König, Cultural Citizenship in India: Politics, Power and the Media (New Delhi: Oxford University Press, 20I6), pp. I3 ff.

${ }^{20}$ Peter Burke, 'History as social memory', in Memory: History, Culture and the Mind, (ed.) Thomas Butler (Oxford: Basil Blackwell, I989); Romila Thapar, Somanatha: The Many Voices of a History (London: Verso, 2005).

${ }^{21}$ Wulf Kansteiner, 'Finding meaning in memory: a methodological critique of collective memory studies', History and Theory, vol. 4I, no. 2, May 2002, p. I9o. 
including this aspect as part of the archive represented by oral memories - thus looking at them also as a 'site of forgetting' - this article problematizes the processes that led to the consolidation of a narrative of the ghetto, looking at how its appropriation on the part of Juhapura's residents as well as of other segregated Muslim neighbourhoods in India contributes to exacerbating their cultural and spatial marginalization. ${ }^{22}$ The uniqueness of Juhapura, of its history and sociocultural location in Ahmedabad, thus becomes a reason to question the long-term role of the state in constantly and practically disempowering strata of the population, forcing them to search for forms of solidarity, as well as means of subsistence and survival, as urban environments become progressively more inhospitable.

\section{Urban informality in the neo-liberal city}

Ideas that neoliberal models in ever-growing cities represent the matrix of urban development contributed to tightening both the epistemological and the normative limits of what fits in the urban environment. ${ }^{23} \mathrm{On}$ the contrary, the notion of urban informality as something that escapes norms of planning policy, evoking at the same time imageries of barely countable demographic growth, entered the mindset of urban planners and theorists from the early 2000 , either as a source of concern or, in the much-criticized view of Hernando de Soto, as an opportunity. ${ }^{24}$ While advocates of neoliberal economic policies glorified the effects they had in leading an increasingly urbanized world down the path of development, strong criticism emerged in urban studies with respect to

${ }^{22}$ Carlo Ginzburg, History, Rhetoric, and Proof (Hanover, NH; London: University Press of New England, 1999), p. 84; James Burton, 'Bergson's non-archival theory of memory', Memory Studies, vol. I, no. 3, 2008, p. 334 .

${ }^{23}$ Richard Sennett, 'The Open City', Urban Age Berlin, November 2006, pp. I-5.

${ }^{24}$ P. Hall and U. Pfeiffer, Urban Future 2I: A Global Agenda for 2Ist Century Cities (London: E and F. N. Spon, 200o); Hernando de Soto, The Mystery of Capital: Why Capitalism Triumphs in the West and Fails Everywhere Else (London: Black Swan, 2000). De Soto's theory on the positive effects of the informal economy for the lowest strata of society has been widely criticised from many angles: see Ray Bromley, 'Power, property, and poverty: why DeSoto's "mystery of capital" cannot be solved', in Urban Informality: Transnational Perspectives from the Middle East, Latin America and South Asia, (eds) Ananya Roy and Nezar AlSayyad (Oxford: Lexington Books, 2004); and, in particular, Jan Breman, The Labouring Poor in India: Patterns of Exploitation, Subordination and Exclusion (New Delhi: Oxford University Press, 2003), Chapter 4 . 
neoliberalism and the city. ${ }^{25}$ Criticisms of the neoliberal doctrine served as a basis for exploring new terrains of theoretical analysis - including, for instance, qualitative appraisals of civil society movements, contestations, and instances of 'insurgency' - and for stressing the importance of local, case-centred analyses to counter the master narrative of the 'extraordinary' and paradigmatic city, highlighting instead the importance of the 'ordinary'. ${ }^{26}$ The critique of the neoliberal city exposed the highly exclusionary character of these development models, thus urging us to better comprehend the diverse sets of factors that contribute to making cities 'unhomely' environments for increasingly larger populations of 'pauperized' and uprooted human beings. ${ }^{27}$

Besides, the idea of an epochal transition towards urban areas has become dominant in public debates (well beyond the borders of academia) and widely shared among political practitioners, irrespective of their orientation. ${ }^{28}$ The purely quantitative methodological approach of this narrative has been criticized from both an empirical and a theoretical perspective. Arguing against this vision, Brenner and Schmid

${ }^{25}$ Neil Brenner and Theodore Nik (eds), Spaces of Neoliberalism: Urban Restructuring in North America and Western Europe (Malden, MA: Blackwell, 2002); Jamie Peck and Adam Tickell, 'Conceptualizing neoliberalism, thinking Thatcherism', in Contesting Neoliberalism: Urban Frontiers, (eds) Helga Leitner, Jamie Peck and Eric Sheppard (New York; London: The Guildford Press, 2007).

${ }^{26}$ James Holston, Insurgent Citizenship: Disjunctions of Democracy and Modernity in Brazil (Princeton: Princeton University Press, 2008); David Harvey, Rebel Cities: From the Right to the City to the Urban Revolution (London: Verso, 2012); Neil Brenner, 'Stereotypes, archetypes, and prototypes: three uses of superlatives in contemporary urban studies', City and Community, vol. 2, no. 3, 2003, pp. 205-216; Jennifer Robinson, Ordinary Cities: Between Modernity and Development (London: Routledge, 2006).

${ }^{27}$ Jamie Peck, 'Cities beyond compare?', Regional Studies, vol. 49, no. I, 2015, p. I72; Darshini Mahadevia, 'Interventions in development: a shift towards a model of exclusion', in Poverty and Vulnerability in a Globalising Metropolis: Ahmedabad, (eds) A. Kundu and D. Mahadevia (New Delhi: Manak Publications, 2002); Gyan Prakash, 'Everyday tactics of survival in the unhomely city', Quaderni Storici, vol. L, no. I49(2), 20I5, pp. 50I52I; Jan Breman, On Pauperism in Past and Present (New Delhi: Oxford University Press, 2016).

${ }^{28}$ In the Indian case, see, for instance, the visions on urban growth released by Congress leader P. Chidambaram when he was finance minister in the Congress-led centre-left government: Shantanu Guha and Shoma Chaudhury, 'My vision is to get 85 percent of India into cities', Tehelka, vol. 5, no. 2I, 3I May 2008 (online edition), and by M. Venkaiah Naidu, current vice-president of India and former union minister for urban development (2014-2017) in the right-wing BJP-led government: M. Venkaiah Naidu, 'How to build the new city', The Indian Express, I9 May 2017 (online access 2 June 2017). 
suggested, for instance, an understanding of the world's urban transition as a 'qualitative shift in the way of life experienced by most people of the planet'. ${ }^{29}$ At the same time, calls to 'provincialize' global urbanism and urban theory followed the same line by inviting us to identify[ing] and empower[ing] new loci of enunciation, from which to speak back against, thereby contesting mainstream global urbanism'. ${ }^{30}$ Within this frame, rethinking the norms of comparison laid the ground for 'decentring' urban theory and proposing analyses that accounted for the differences rather than subscribing to the idea of a linear stream of urban development. ${ }^{31}$

The rapid acceleration in the rates of urbanization over the last four decades and the transformations brought about by neo-liberal economic models still provide a dense smokescreen that conceals long-term explanations for different patterns of growth, trajectories of social and cultural recognition, and forms of contestation and negotiation vis-à-vis public authority. ${ }^{32}$ The aim of this study is thus to make sense of the way in which global phenomena interact with pre-existing conditions that are place-specific. It is the very dichotomy between pre-existing conditions and global patterns of urbanization that needs to be

${ }^{29}$ Neil Brenner and Christian Schmid, 'The "urban age" in question', International Fournal of Urban and Regional Research, vol. 38, no. 3, 2014, p. 742.

30 The reference to 'provincializing' global urbanism is mainly found in the work of Eric Sheppard and Helga Leitner. See, in particular, Eric Sheppard, Helga Leitner and Anant Maringanti, 'Provincializing global urbanism: a manifesto', Urban Geography, vol. 34, no. 7, 2013, p. 895; M. Werner, 'Contesting power/knowledge in economic geography: learning from Latin America and the Caribbean', in Wiley-Blackwell Companion to Economic Geography, (eds) T. J. Barnes, J. Peck and E. Sheppard (London: Wiley-Blackwell, 2012), pp. I32-I46; Helga Leitner and Eric Sheppard, 'Provincializing critical urban theory: extending the ecosystems of possibilities', International Journal of Urban and Regional Research, vol. 4o, no. I, 20I5, pp. 228-235.

${ }^{31}$ Colin McFarlane and Jennifer Robinson, 'Introduction - experiments in comparative urbanism', International fournal of Urban and Regional Research, vol. 33, no 6, 2012, pp. 765-773; Jennifer Robinson, 'Thinking cities through elsewhere: comparative tactics for a more global urban studies', Progress in Human Geography, vol. 40, no. I, 2016, pp. 3-29; Jane M. Jacobs, 'Commentary - comparing comparative urbanisms', Urban Geography, vol. 33, no. 6, 2012, pp. 904-9i4; Janet Abu-Lughod, New York, Chicago, Los Angeles: America's Global Cities (Minneapolis, MN: University of Minnesota Press, 1999).

${ }^{32}$ Lisa Bjorkman, 'Becoming a slum: from municipal colony to illegal settlement in liberalization-era Mumbai', International Fournal of Urban and Regional Research, vol. $3^{8}$, no. I, 20I4, pp. 36-59; Tommaso Bobbio, Urbanisation, Citizenship and Conflict in India. Ahmedabad 1900-2000 (London: Routledge, 2015); Andre Arnisson Ortega, 'Desakota and beyond: neoliberal production of suburban space in Manila's fringe', Urban Geography, vol. 33, no. 8, 2012, pp. III8-II43. 
discussed in an analysis that looks into the interactions, contestations, and adaptations that made people in different contexts practise their city in peculiar ways.

Engaging with the invitation of subaltern urban critique to make the invisible visible and fill in the silence in official archives and annals concerning the most vulnerable strata of society, this article suggests that the ways in which urban informality is framed and dealt with in Ahmedabad should be understood through the lens of history. ${ }^{33}$ It does so by looking at how a specific area of the city changed over the span of nearly half a century, how the public authority dealt with it, and how it acquired different meanings in the social and cultural geography of the city.

An emphasis on the long term accounts for one of the features that is at the same time typically local and irreducibly global in the rise of mega-cities across the world: the fact that a large portion of urban growth is founded on something that is deemed temporary, transitory, and, more often than not, illegal. ${ }^{34}$ Across the twentieth century, increasingly larger urban populations settled to live in slums and various other forms of informal settlements. This in itself constitutes a fundamental chapter in the history of how urban territories have been intended and administered, understood and practised during the twentieth century. While in many cases slumdwellers have been living in the city for generations, in the lexicon of policymakers and the understanding of formal citizens, their existence and their very presence in the city are temporary, much like their huts and tenements. Furthermore, reducing the living spaces of millions of urban dwellers to the category of informality has deeply influenced the way in which urban administrators have managed the territory of the city and understood the living conditions of the masses of urban poor. ${ }^{35}$ With some exceptions, urban administrators rarely use the words 'informal'

${ }^{33}$ Ananya Roy, 'Slumdog cities: rethinking subaltern urbanism', International fournal of Urban and Regional Research, vol. 35, no. 2, 2011, pp. 223-238; Amitabh Kundu, 'Foreword', in Subaltern Urbanisation in India: An Introduction to the Dynamics of Ordinary Towns, (eds) Eric Denis and Marie-Hélène Zérah (New Delhi: Springer, 2017), pp. v-xi.

${ }^{34}$ Slums are frequently defined 'as a compact settlement [...] with a collection of poorly built tenements, mostly of temporary nature, crowded together usually with inadequate sanitary and drinking water facilities in unhygienic conditions'. Report of the Committee on Slum Statistics/Census (Ministry of Housing and Urban Poverty Alleviation, Government of India, 2011).

${ }^{35}$ Ananya Roy, 'Urban informality: toward an epistemology of planning', Fournal of the American Planning Association, vol. 7I, no. 2, 2005, pp. I47-I58. 
and 'informality' in official documents, preferring instead indirect periphrases that refer to a milieu where people live in extra-legal, highly populated, but at the same time barely quantifiable settlements, and are engaged in low-paid, insecure, and unregulated economic activities. ${ }^{36}$ Whatever the definition in urban policy documents, the specific features of neo-liberal models of urban development made the city aggressively unhomely for the urban poor by emphasizing aspects of illegality related to slum settlements and linking it to the people's condition of marginality. ${ }^{37}$ At the same time, city spaces emerged as 'the most hospitable environment for business and investment', becoming the predominant sites 'upon which the neoliberal agenda has played out', and the label 'mega-city' came to symbolize a promise of modernity, public order, efficiency, and economic growth. ${ }^{38}$ While Ahmedabadwhich acquired the mega-city label in 2005-gradually became the showcase of the so-called Gujarat model of development that would be promoted all over India, the concurrent consolidation of increasingly segregated spaces showed how religious or caste belonging overlapped with economic status in defining residential patterns in the city. ${ }^{39}$

The trajectory of a place like Juhapura shows how, in certain situations, the rhetoric of urban development acted as a Trojan horse to delegitimize entire communities and their spaces through everyday practices. Here we see that 'informal' - that is, extra-legal, unregistered, arbitrary - does not just apply to the spaces, economic activities, and dwellings of the Muslims of Ahmedabad, but also to the practices that annihilated them as citizens. Again, with its selective absence and failure to provide basic services and deliver welfare, the state has a central role in the crystallization of the dynamics of discrimination.

${ }^{36}$ A significant exception is the Gujarat State Urban Slum Policy of 2010, in which 'informal settlements' is used along with the term 'slum'. Gujarat State Urban Slum Policy (Urban Development and Urban Housing Department, Government of Gujarat, 2010).

${ }^{37}$ Ananya Roy, 'Why India cannot plan its cities: informality, insurgence and the idiom of urbanization', Planning Theory, vol. 8, no. I, 2009, pp. 76-87; Francesco Chiodelli, 'Planning illegality: the roots of unauthorised housing in Arab East Jerusalem', Cities, vol. 29, 2012, pp. 99-106.

${ }^{38}$ Mona G. Mehta, 'Ahmedabad: the middle-class megacity', South Asian History and Culture, vol. 7, no. 2, p. I93; see also Swapna Banerjee-Guha, 'Neoliberalising the "urban": new geographies of power and injustice in Indian cities', Economic and Political Weekly, vol. 44, no. 22, 2009, pp. 95-107.

${ }^{39}$ Banerjee and Mehta, 'Caste and capital', pp. I84-185. 


\section{Early post-colonial understandings of slums}

After my marriage we moved to Ramol, then we moved to Hatijan, after that we went to Isanpur, then Lambha and finally here, to Vasna. At that time, Ramol village was in the open countryside, there were only fields, dust and stones. There we spent one year, and another eight months in Hatijan. We were always trying to find fields for grazing our goats [...]. For moving to another place, we would put everything on a donkey, and then move where fields were available. At that time we used to sleep in the open. When we arrived here [in Vasna] it was not possible to keep cattle anymore, people from the Municipality took all the cattle away, so we did not have anything more to sell. At that time, we started mason work.

When we arrived here there was nothing, just seven-eight huts were present. We used pieces of cloth and wood to build our huts and, during the monsoon, we covered them with paper or plastic [...]. The lights from Vasna village were visible from here, and we could also see the bus coming from the village. The flats here in front of the road came up very recently, now you cannot see any field from our house. ${ }^{40}$

Testimonies like this one are very frequent among older residents of the slums and urban villages around Ahmedabad. Following the life and housing trajectories of slumdwellers allows us to trace a living map of the various phases of the city's expansion: in many cases internal migration exposes people's search for those border areas between the city and the countryside where they could keep on finding rural sources of livelihood - such as grazing some cattle - while at the same time being in touch with the city and the opportunities of casual labour that it offered, like being employed in mason work, or as day labourers in the city's factories, or street vending. ${ }^{41}$ For many families, the need to maintain such contact between urban and rural was a matter of survival but, at the same time, contributed to creating an ambiguity in the ways that urban administrators understood and dealt with issues around the rise of forms of extra-legal, substandard settlements and their inhabitants.

What emerges from the city administration's official accounts is a persistent approach towards dealing with urban change, not only in its demographic, spatial, and infrastructural dimensions, but also as behavioural and cultural issues. More than poor-quality settlements, slums were considered lifestyles - in particular, pre-urban 'ways of

\footnotetext{
${ }^{40}$ Interview XV, 80-year-old casual labourer, I8 October 2008, Guptanagar slum, Vasna (now the area facing Juhapura on the southern 'border').

${ }^{41}$ Jan Breman, The Making and Unmaking of an Industrial Working Class; Sliding Down the Labour Hierarchy in Ahmedabad, India (New Delhi: Oxford University Press, 2004).
} 
living', as the Town Planning Organisation of the Indian Ministry of Health made clear in 1958: the slumdweller is disinclined to give up many rural habits which are incompatible with an urban way of living. ${ }^{42}$ References to pre-urban habits constitute a sort of sub-text that emerges constantly in official reports on urban development, infrastructure, or sanitation. Interestingly enough, the link between substandard housing conditions in slums and the lifestyles of slumdwellers has been consolidated through a vocabulary that places responsibility directly on the urban poor. They are responsible for the miserable conditions of their housing and living spaces, but this affects the entire city, as slums are a nuisance for all urban society. ${ }^{43}$

During the I96os, public administrations in Ahmedabad and Gujarat began to deal with what they perceived as the uncontrolled growth of slum settlements. In order to provide a definition that would allow them to quantify and survey those areas, interestingly they identified two areas of concern that qualified an area as a slum: first, slums were 'a source of danger to the health, safety or morals of the inhabitants of that area or of its neighbourhood' and, second, structural deficiencies made the homes in those areas 'unfit for human habitation'. ${ }^{44}$ These two aspects are obviously interdependent and the text clearly related those elements that were identified as structural, somehow external, such as 'repair, stability, freedom from dump, natural light and air, water supply, drainage and sanitary conveniences' with behavioural aspects that affected the people living in a slum.

The Slum Areas (Improvement, Clearance and Redevelopment) Act was promulgated in 1973, a decade after the state government (through the Gujarat Housing Board Act of I96r) and the Ahmedabad Municipal Corporation had begun to engage with issues relating to housing, infrastructure, and uncontrolled urban development. The Act reflected a widely shared identification of the slum not only with a space- degraded, overcrowded, and unregulated - but also with the people who lived in it:

The habits and living methods have spoiled the area and made a slum once again. From this example, it is true both ways that slum make people dirty and

\footnotetext{
${ }^{42}$ Ministry of Health, Slum Clearance and Urban Renewal in Delhi (New Delhi: Town Planning Organisation, I958).

${ }^{43}$ Asher Ghertner, 'Nuisance talk and the propriety of property: middle class discourses of a slum-free Delhi', Antipode, vol. 40, no. 4, 2012, pp. II6I-II87.

${ }^{44}$ The Gujarat Slum Areas (Improvement, Clearance and Redevelopment) Act 1973 (henceforth Gujarat Slum Act 1973), Government of Gujarat, I973, pp. I34-135.
} 
many a times such people make the slum. The common habits like throwing garbage, keeping animals attached to living places, spreading water near the houses, $[\ldots]$ taking liquors, bidies etc. affect their health and living conditions. The slum mentality, which can be seen here, has been continuously (sic) even though the dwellings are newly constructed.

We must change the habits of the people, their group behaviour, their thinking and attitude towards their life. [...] Before any physical planning is done, their attitude and mentality should be changed by way of social programme. ${ }^{45}$

Examples of this kind mark one of those continuums that characterize the history of how urban administrators understood and dealt with extremely poor and unplanned settlements. In fact, from the early phases of urban politics in the I920s, the rapid and generally uncontrolled immigration of migrant labourers from outlying areas raised issues relating more to the capacity of migrants to adapt to the urban environment than to the ability of the administration to provide infrastructure and services to the new shantytowns. ${ }^{46}$ Yet it was not until the mid-twentieth century that the Municipal Corporation of Ahmedabad (AMC) began to deal with slums, urban poverty, and the total lack of basic services as a structural issue that affected the city as a whole. While the understanding that the poor migrants were somehow culpable for the creation of slums was widely shared, there is a fundamental difference between the general tone of the I973 Gujarat Slum Areas Act and the legislation that followed in the Ig8os, I9gos, and 2000s. In the I973 Act the public authority clearly took on the responsibility for dealing with the issue of slums in the city: the Act prescribes clear paths that would lead to the demolition of a slum or to its redevelopment through infrastructural improvements; it lays down the procedures that slumdwellers needed to follow to appeal the authority's decisions; and, with the creation of a Slum Clearance Board, it created a specific body, publicly funded, with the goal of prevailing over the slums in the city through action at different levels.

${ }^{45}$ H. L. Vadi, 'A Case Study of Slum Condition in Ahmedabad', Thesis, School of Architecture, Centre for Environmental Planning and Technology, I969, p. 64 [emphasis added].

${ }^{46}$ Siddhartha Raychaudhuri, 'Colonialism, indigenous elites and the transformation of cities in the non-Western world: Ahmedabad (West India), I89o-I947', Modern Asian Studies, vol. 35, no. 3, 2001, pp. 677-726. For instance, in 1927 Sardar Patel, as head of the municipal administration, pointed his finger at the rising population of urban dispossessed, who 'generally consider themselves free to cause nuisance, irrespective of time and place', quoted in Narhari Parikh, Sardar Vallabhbhai Patel (Ahmedabad: Navajivan Publishing House, I953), pp. 270-27I. 
Although these principles mostly remained on paper, and the cycle of repeated evictions, re-encroachment, and re-evictions frequently manifested in certain slums, giving slumdwellers a sense of extreme helplessness before the arbitrary decision-making power of the public authority, the difference with what came afterwards is striking. There is no reference in the 1973 Act to legal or illegal status or to the duration of land tenure, while it is recognized that slums are regulated by some sort of land market, where there are 'owners', rent payers, and mediators. ${ }^{47}$ Policy guidelines towards the end of the century in fact reflect a shifting paradigm in conceiving the role of the state, betraying a manifested intolerance towards the fact that slums and slumdwellers had greatly increased over the decades. ${ }^{48}$

As the next section argues, the effort made by the AMC and the state government during the I970s to better control the dynamics that were causing a rapid expansion of the urban territory beyond the traditional limits of the municipality produced categorizations that stiffened understandings of what were to be considered legal or illegal housing practices. Discourses that equated the slums (a nuisance and moral threat to the rest of the city's space) with the people who lived in them contributed to deeply delegitimizing the urban poor as citizens on both the structural and cultural levels. On the one side, the chronic incapacity of the AMC to provide basic infrastructure to slum areas relegated increasingly higher shares of the urban population to live in extremely degraded conditions, while the formulation of a paradigm relegating slums to a status of illegality discouraged people from engaging in any kind of financial effort to improve their houses and public spaces. ${ }^{49} \mathrm{On}$ the other side, the identification of slum spaces with 'pre-urban' behaviour directly affected the slumdwellers' relationship with the public authority, thus undermining their possibility of feeling that they belonged to the city as well as - in the words of French anthropologist

${ }^{47}$ Gujarat Slum Act i973, p. I33.

${ }^{48}$ Project Proposal for Slum Upgrading for the City of Ahmedabad, Vol. I (Ahmedabad: Ahmedabad Municipal Corporation, I984), pp. 2-3.

${ }^{49}$ In 1976 Nimish Patel reported that the slum of 'Lakhudi was demolished twice in the last ten years and its inhabitants fined as many as II3 times U.S. \$o.8o per household for illegal encroachment of the public land.' This notwithstanding, its residents rebuilt the slum each time after the demolitions. Nimish Patel, 'Urban Dwelling Environments: Ahmedabad, India. Case Studies, Urbanization Alternative', MArch thesis, Massachusetts Institute of Technology, 1976. 
Gervais-Lambony - their 'adherence to the city, to its existential forms and its values. ${ }^{50}$

\section{The invention of informality in Ahmedabad (1970s-1980s)}

The first time they [planning authorities] had come was around twenty years ago, then they came again ten years ago, and now they want to demolish the slum once again. Twice the government demolished these pakka houses and all our expenses, all the money we spent to build our homes, went into water.

They illegally demolished our homes saying that we were staying here since twenty years, but we said that we were living here not since twenty years, but much longer than that! I have the proof, we have the receipt for the Municipality tax that we pay, we have the Voter's ID card, we also have the Ration Card. All the documentary proofs are with me, whatever the government needs, I have it but it does not stop them to demolish our homes [...].

They said that they had provided land for us on a different site, but we did not go. They wanted to send us to very far places but we all had our lives, our jobs here, so we did not want to go. We did not go where they told us to go [...], and for around twelve months slept in the open right in front of the area. We remained here and the Municipality demolished forty-two huts at a time. But then they did not build anything on this land, so we came back and made our houses here again.

Nobody listens. The law is blind - the law is blind. This world wants the poor to die. By crying like this we have become old, now again they just want to move us from here, to make big five star hotels and where do they want to dump poor people? At Kadi, Kalol, Viramgam, Sanand where there is jungle and we will die. ${ }^{51}$

Until the r96os the Ahmedabad Municipal Corporation had promoted projects to provide alternative housing for the urban poor. ${ }^{52}$ Most of these attempts ended in failure as the new houses did not meet either their needs or provide their basic requirements in terms of facilities (water, sewerage, electricity), and so the relocated people abandoned or sold them. In the subsequent decade, the entire chain linking urban immigration, the emergence of slums and other forms of unregulated dwellings, extension of municipal control, evictions, and relocations changed significantly as the Municipal Corporation, along with the

${ }^{50}$ Philippe Gervais-Lambony, Territoires Citadins. Quatre Villes Africaines (Paris: Belin, 2003), p. 95. See also Rainer Baubock, 'Reinventing urban citizenship', Citizenship Studies, vol. 7, no. 2, 2003, pp. 139-160.

${ }^{51}$ Interview XXV, 73-year-old casual labourer, 5 December 2008, Shahpur (riverfront slum, demolished).

${ }^{52}$ Darshini Mahadevia, Globalisation, Urban Reforms and Metropolitan Response: India (Ahmedabad: School of Planning, Centre for Environmental Planning and Technology, in association with Manak, 2003). 
Gujarat state government, made new and greater efforts aimed at better controlling the expansion of the urbanized areas. As demographic growth reached new peaks and the city's population rapidly moved towards the two million mark, urban and state authorities addressed the urgent need to better understand the dynamics that were transforming the city's territory. ${ }^{53}$

In an effort to extend their control over the expanding city, the state government and the AMC created a new body that was specifically designated 'to carry out the sustained planned development of the area falling outside the periphery of Ahmedabad Municipal Corporation'. ${ }^{54}$ In the first years of its existence (1976-1980), the main efforts of the Ahmedabad Urban Development Authority (AUDA) were devoted to categorizing and understanding the growth patterns of recently constructed areas and the infrastructural deficiencies deriving from the fact that new housing complexes were often outside municipal limits. ${ }^{55}$

At the same time, the AMC launched an initiative to conduct the first slum census, with the aim of better understanding the issues relating to land tenure; residency; social, regional, and caste stratification; as well as economic and labour distribution in the slum areas of the city. ${ }^{56}$ Here, for the first time, the definition of what was to be considered a slum relied on the principle of illegality, which added to the previous criteria sanctioned by the Gujarat Slum Act of $1973 .{ }^{57}$ In line with the overall effort to understand and control unbridled urban growth, through the slum census, urban authorities produced a more rigid categorization of what was to be considered legal and illegal in terms of land use, what was to be formally recognized and what was not. On the one hand, the huge amount of knowledge that urban authorities had

${ }^{53}$ Meera Mehta, Dinesh Mehta and Shivanand Swamy, Metropolitan Housing Market: A Study of Ahmedabad (New Delhi; London: Sage Publications, 1989).

${ }^{54}$ Ahmedabad Metropolitan Region, Part I (Ahmedabad: Ahmedabad Urban Development Authority, 1978). It should be noted that similar bodies were created in the major Indian cities in the same years. To name a few, the Mumbai Metropolitan Region Development Authority (MMRDA) was established in 1974, the Kolkata Metropolitan Development Authority in 1979, and the Chennai Metropolitan Development Authority in 1972 .

${ }^{55}$ Ahmedabad Metropolitan Region Part I; Ahmedabad Metropolitan Region Part II (Ahmedabad: Ahmedabad Urban Development Authority, I979); Ahmedabad Urban Complex (Ahmedabad: Ahmedabad Urban Development Authority, i980).

${ }^{56}$ Report on Census of Slums in Ahmedabad, I976 (henceforth Census of Slums 1976) (Planning Cell, Ahmedabad Municipal Corporation, 1977).

${ }^{57}$ Ibid., p. 2. 
acquired during the I97os provided the basis for more effective and focused policy interventions and development plans, but, on the other, it contributed to crystallizing categories through which the urban space and society were understood and looked upon.

Paradoxically, all these efforts contributed to exacerbating, rather than reducing, issues of spatial disparity as well as the perceived dichotomy between legal and illegal settlements and their residents. First, while both substandard settlements and upper- and middle-class societies fell outside municipal limits, and thus were formally unregulated, public authorities adopted very different policy approaches towards them. Upper class societies were to be brought under the remit of the urban administration, so that they could fall under town planning schemes and produce revenue. On the contrary, slums continued to be the recipient of policies aimed either at relocating slumdwellers or providing them with basic services (water, sewerage, electricity) but without moving towards a formal recognition of their right to tenure or at least granting them tenure security. Secondly, from the mid-Ig8os onwards, the shift in urban policies towards the increasing involvement of private capital in infrastructure building and in the provision of services made slum areas even more backward as they were seen as an obstacle to development plans rather than as a reality to be understood and dealt with. ${ }^{58}$

The decade from 1975 to 1985 represents a crucial passage in the consolidation of a different model of urban planning and therefore the creation of an even greater distinction between urban formality and informality as well as in the crystallization of the formal/legal and informal/illegal equations. The story of a relocation project-turnedslum and then Muslim sub-city shows how the line separating formal and informal settlements is, in fact, very unstable and moves over time.

\section{From jungle to 'ghetto'}

When we arrived, it was not very safe here as mixed communities [Hindus and Muslims] lived. At first, we did not feel nice but then as time passed we started liking it.

[Hindus started going away], there was no fight between Hindu and Muslim here but they themselves left their homes and went away. As more Muslims

\footnotetext{
${ }^{58}$ Vinit Mukhija, 'The contradictions in enabling private developers of affordable housing: a cautionary case from Ahmedabad, India', Urban Studies, vol. 4I, no. II, 2004, pp. $223 \mathrm{I}^{-}-2244$.
} 
arrived and settled here, Hindus left their homes and their presence in the area started reducing.

No one have legal property rights now on the houses of Shanklit Nagar. Once we start paying tax and everything else then we will have them. All the houses in Juhapura have Bakshishnama [gift deed]. This land was given as a donation, so obviously the money spent in the construction work has to be re-paid. Nobody has paid that money until now, so its interest has kept on increasing and has become very much now.

At that time, the river flooded and destroyed the areas near the banks like Khanpur, Behrampura. People who used to live there were given this land. Then those people sold their houses to others and so on...

The house opposite to ours is the same house that was given to that family from that river area, but that is the last one. Those who got such houses have already shifted back to the river and took money after selling them. While some other people just broke into the locked houses by breaking the locks and started staying in them. Even that they sold and went away. They went to live in societies. ${ }^{59}$

How did the story of the biggest ghetto in south Asia begin? The first housing on the site of modern-day Juhapura dates back to the end of the I97os. Prior to that time, 'it was all jungle', a description often used by older slumdwellers. By this they mean that the area was predominantly rural, with some farms scattered between the villages of Vasna, Makarba, and Sarkhej on the southwestern edge of Ahmedabad. Forty years later, Juhapura now appears as a medium-sized town, growing off the main city. It has its own 'slum' which, as we shall see, is the original colony, a main road, and quite a clear-cut division between lower middle class housing complexes and the quarters where more affluent families built their bungalow houses, as well as the new societies comprising high-rise towers under construction that are advertised as 'modern' apartments. All these subdivisions are clear to the residents and embody memories of the various phases that led this part of Ahmedabad to become the 'largest Muslim ghetto in South Asia', as Ahmedabadis of both communities colloquially define it (see Map 2). Can we read this trajectory in the light of new urban planning paradigms and communal mobilizations that became dominant in the city's industrial crisis in the I980s?

The story of how such a peripheral area came to be settled and gradually slipped out of the control of the Municipal Corporation shows that the boundaries between legal and illegal practices, for instance regarding property rights over a house or land tenure, are porous and require constant redefinition. The area was, in fact, originally planned and realized by the Municipal Corporation with the aim of relocating

${ }^{59}$ Interview IV, 6I-year-old tailor, I July 2008, Shanklit Nagar. 


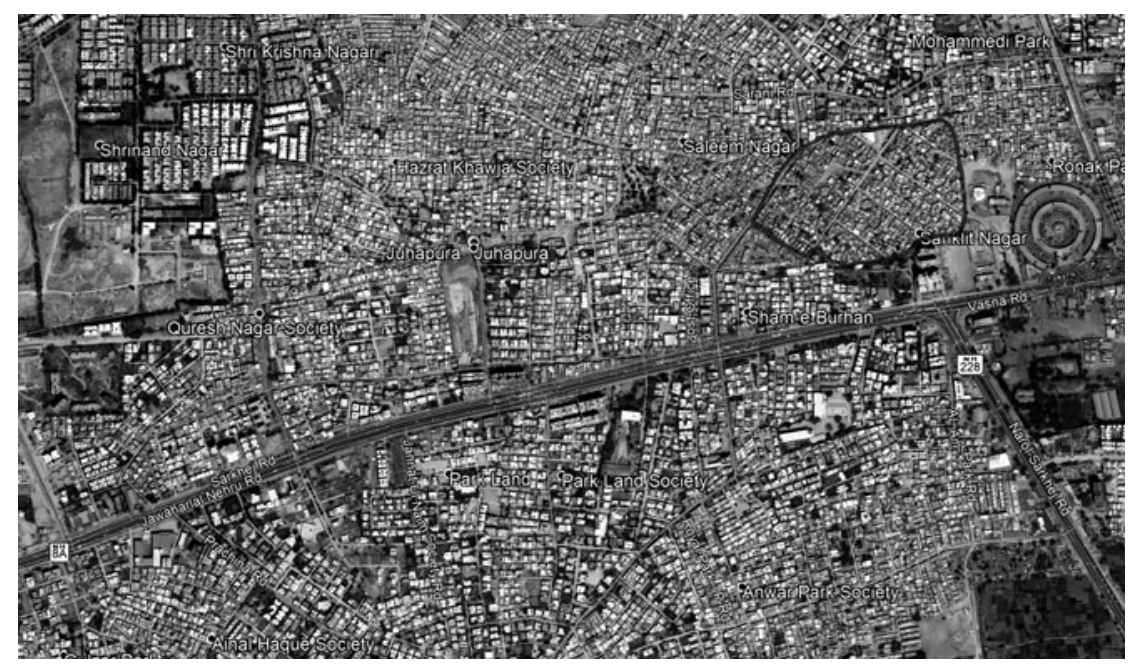

Map 2. Aerial view of Juhapura: the borders of Shanklit Nagar are delineated to highlight the geometric and ordered structure of the Integrated Urban Development Project of 1978. Source: This map is derived from Google Earth; the boundaries of Juhapura neighbourhood were drawn by the author from local maps, and from surveys conducted and information collected by him.

residents of riverfront slums, after the heavy flooding of the Sabarmati River had wiped out their homes in 1973. The AMC thus had the double intent of providing new homes to thousands of displaced people and getting rid of slums that were located in the very centre of the city along the riverbanks. ${ }^{60}$ The 'Integrated Urban Development Project' was then launched as a pilot and innovative initiative in the area known as Shanklit Nagar: the project was advocated by two local NGOs - the Ahmedabad Study Action Group (ASAG) and Saint Xavier's Social Service Society (SXSSS) - along with the AMC in order to relocate 2,250 families living in 20 different clusters on the Sabarmati riverbanks. Interestingly, there is a higher representation of Muslims in Shanklit Nagar (44 per cent) than in the city as a whole (I5 per cent), which could tell of both the greater backward status of Muslims in the city and of the fact that the area became a privileged destination for the

${ }^{60}$ The riverbank slums were at the centre of many controversies throughout the twentieth century, with the AMC always attempting - sometimes with at least temporary success - to demolish them and move the slumdwellers to other locations. Recently, with the completion of the widely advertised 'modern' Sabarmati Riverfront Development Project, most of the unplanned dwellings along the riverbanks have finally been relocated. 
intra-urban migration of Muslim families in subsequent years. ${ }^{61}$ Two of the elements that made this project different from the previous ones were that future residents were involved in the preliminary design phase in meetings and focus groups, so that the houses would answer their needs, and that through the payment of regular instalments to the AMC, they would have been granted full ownership of their homes. ${ }^{62}$ In this way, residents were involved in the entire process of planning and construction, and were made financially responsible for their new homes.

From the testimonies of original residents of Shanklit Nagar, as well as of the nearby urban village-turned-slum of Vasna, several elements explain the process that led many residents to abandon the colony and progressively made it a community-dominated area, attracting new Muslim residents from the city centre. Although officially well planned, the houses were poorly serviced, which contributed to strengthening a feeling of degradation and alienation from the city. Added to this, the colony's distance from the city centre - about Io km - fostered a feeling of isolation in the people who had previously lived, albeit illegally, on the riverbanks right at the conjunction between the bazaars of the Old City and the newly developing service and residential neighbourhoods on the western side of the Sabarmati River. As already mentioned, in the narratives of many older residents, they recurrently use the term 'jungle' to describe what the area corresponding to modern-day Juhapura looked like at the end of the ig7os.

Distance from the city and lack of infrastructure and amenities played a role in making the newly built colony of Shanklit Nagar look degraded within a few years. This, along with the fact that allottees had to pay monthly instalments to the AMC, made those houses less attractive for the displaced riverfront slumdwellers, many of whom started abandoning them to go back to rebuild the former slum. However,

${ }^{61}$ Joseph Block, 'Communal conflict, NGOs, and the power of religious symbols', Development in Practice, vol. 7, no. I, I997; Kirtee Shah, 'The Integrated Urban Development Project-Ahmedabad: A Case Study in Public Private Partnership for Development', Seminar on Public/Private Sector Partnerships (PPP) for Urban Infrastructure and Service Delivery, Seoul, South Korea, 2-4 April 2002.

62 ઓળખ પત્ર, Integrated Urban Development Project-Vasna, Ahmedabad, I978 (henceforth IUDP card; see Figure I). Recognition card and agreement of an original resident of the Shanklit Nagar Society, author's private archive. See also Ahmedabad Study Action Group (ASAG) 'Concept and origin', Introductory paper of the NGO ASAG (Ahmedabad, India, I99I). 


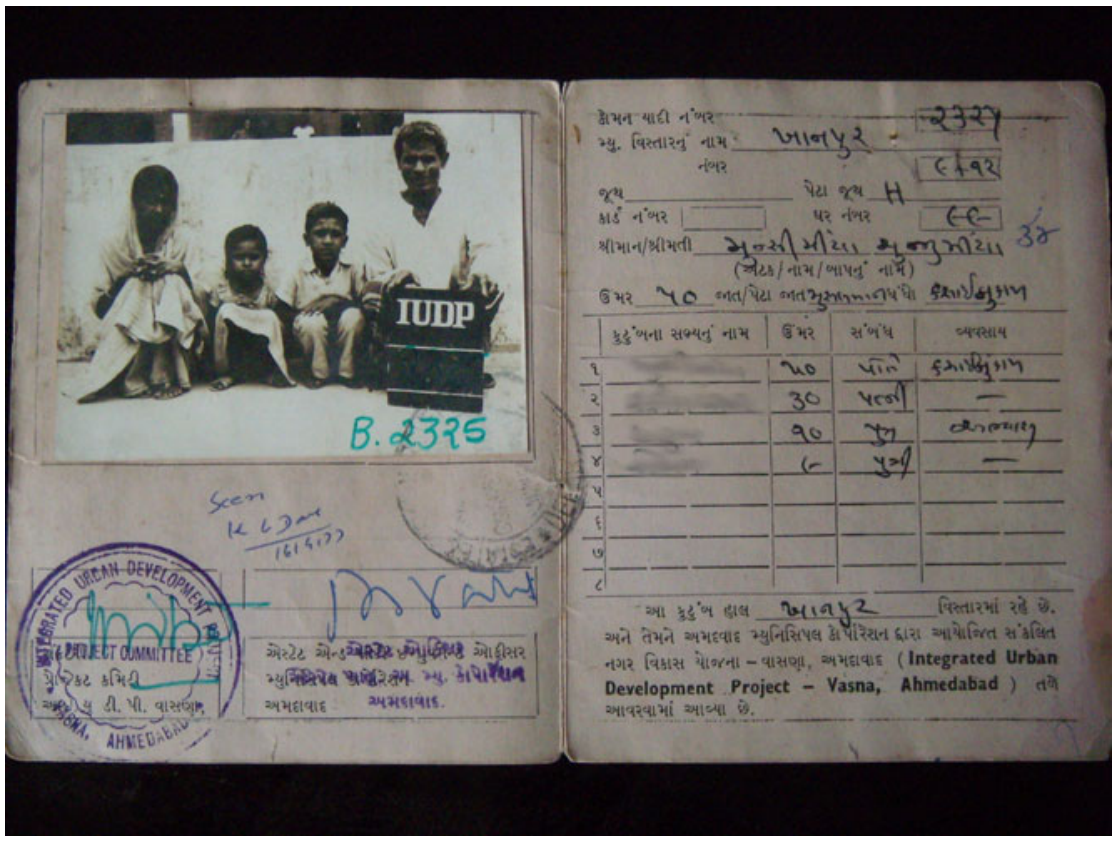

Figure I. Inside of the IUDP card, which assigned a house within the Integrated Urban Development Project, 1978. Source: Author's personal archive. (The name of the card holders have been blurred to protect their privacy.)

once a house had been assigned, residents were legally bound not to sell or rent it to third parties and so they either abandoned them (as some interviewees mentioned) or informally sold them to others who were interested in moving there. ${ }^{63}$ In this way, the model colony of Shanklit Nagar gradually slipped out of the control of the AMC: in the memories of some original residents, many houses were assigned but never occupied and there was availability of free homes almost from the very beginning, so people arrived there, broke the locks on the doors, and occupied them. Thus, Shanklit Nagar was first-and-foremost a failed municipal project for the relocation of slumdwellers and their integration in the formal city.

Vacant homes and the availability of land around the colony became an opportunity for other people who were looking for affordable accommodation and could no longer cover the costs of living closer to the city centre. Among those who began to move to Juhapura were

${ }^{63}$ IUDP card, p. 4. 
several families of long-term residents of Ahmedabad and lower income casual labourers for whom changing their area of residence was a frequent constraint when the housing market (either formal or informal) or the lack of job opportunities forced them to do so. In this regard, Shanklit Nagar provided a favourable opportunity for those who lived a life straddling the urban and rural, working casually as manual labourers, but at the same time relying on small farming or herding. What emerged with surprising frequency in the memories of peripheral slumdwellers was their habit of changing areas in order to remain midway between city and countryside as the urban territory expanded. In some cases, respondents recalled frequent lifelong internal migrations, giving the sense of quasi-nomadic lives within the cityscape. ${ }^{64}$

From the mid-Ig8os, a second pattern gradually emerged alongside the process of 'slumification' of the colony: people who migrated towards that area were predominantly Muslim. In the words of an 8o-year-old woman, who claimed to have been the last Hindu resident of Shanklit Nagar (she recalled having moved to the nearby Hindu slum of Vasna after the 2002 pogroms), the original colony for the riverfront slumdwellers was soon surrounded by more shacks that housed those who were steadily moving there from the city as a consequence of the increasingly frequent waves of riots between I986 and $1992 .{ }^{65}$ What is today called Juhapura, then, is the neighbourhood that grew up around the first original 'Integrated Urban Development Project' for relocating the dwellers of the flooded riverbanks (see Map 2).

While the availability of open land made it a desirable location for lower income families, other factors contributed to characterizing it as a Muslim neighbourhood: among these, the increasing level of communal tensions and the recurrence of episodes of collective violence against Muslims during the ig8os played a determinant role. Muslims in the city began to feel that their religion made them a target for violent action and, at the same time, the crisis in the industrial sector contributed to the disaggregation of forms of solidarity between Muslim and Dalit people, who had largely shared work and living spaces in the industrial areas. As Ornit Shani argued, Hindu fundamentalist rhetoric successfully targeted those spaces of discontent and loss of security

\footnotetext{
${ }^{64}$ Interview XV, 8o-year-old casual labourer, i8 October 2008, Vasna; Interview XVII, 82-year-old cart puller, iा/i6 July 2008, Vasna.

${ }^{65}$ Interview VIII, 8o-year-old stonemason, II July 2008, Vasna.
} 
opened up by the industrial crisis, with the aim of bringing into the Hindutva fold lower-caste former industrial workers in opposition with Muslims. ${ }^{66}$ The interaction of these elements, which lay at the basis of the extensive wave of riots that shook the city between 1985 and 1986 , and then again in 1992, made moving away from the mixed neighbourhoods of the old city and the former industrial areas a desirable choice for many Muslims. ${ }^{67}$

Expansion first took place in what was the original colony of Shanklit Nagar. It grew into a slum-like, underserviced area during the ig8os following the riots that primarily struck the former industrial neighbourhoods. Subsequent episodes of violence, in particular the 1992 riots that accompanied the demolition of the Babri Masjid, brought violence into middle-class neighbourhoods for the first time. For middle-class Muslim families their economic status was no longer a guarantee of security, and so slowly but steadily they also began to take part in the partitioning of urban territory along religious lines. In those years, groups of larger, bungalow-type houses appeared on the opposite side of state highway NH8A, which marked the southern edge of Shanklit Nagar. ${ }^{68}$ These comprised Juhapura's first middle and upper class housing societies and represented the beginning of an internal spatial differentiation, which added complexity to the apparently homogeneous categorization of a Muslim neighbourhood. ${ }^{69}$ Thus the state highway progressively became an internal marker for defining 'poor' (the former Shanklit Nagar and its surrounds) and 'wealthy' Juhapura. As both sides of the road were equally beyond the reach of the municipality in terms of infrastructure and service delivery, the class divide emerged even more glaringly.

${ }^{66}$ Shani, Communalism, caste and Hindu nationalism, in particular Chapters 2 and 5. It is not within the scope of this article to analyse in depth the various elements that interacted in favour of the ascendancy of Hindu fundamentalism during the ig8os, but it is important to highlight that many of the dynamics that became evident on a national scale with the Babri Masjid mobilization in the early I99os were played out in Ahmedabad much earlier.

${ }^{67}$ Such waves of riots must be also seen in the context of the mobilization against the proposed 'reservations policies', which had begun in I98I in Ahmedabad, again in anticipation of a dynamic that a decade later would acquire a national dimension. Howard Spodek, 'From Gandhi to violence: Ahmedabad's 1985 riots in historical perspective', Modern Asian Studies, vol. 23, no. 4, I989, pp. 765-795.

${ }^{68}$ Interview XIII, 74 year-old college professor, 2I September 2008, Juhapura.

${ }^{69}$ In this regard, 'Muslim city' is somehow more appropriate than 'ghetto', as it better corresponds to the various levels of differentiation, according to income, period of arrival, even religioius belief, that a socio-territorial analysis of the area reveals. 
The 2002 pogroms represented a further step in the process of isolation and segregation of the area and its residents. Adding to the increasing number of people who were deliberately choosing to move there, the indescribable violence of 2002 left behind a large population of victims who had lost their property and, in many cases, were not able to return to their homes after the violence had subsided. ${ }^{70}$ Many of the refugee camps, which had been set up during those months, were gradually transformed into permanent or semi-permanent relief colonies. This not only meant a net increase in the number of residents, but also had much deeper effects on the religious make-up of the area: most of the relief colonies for the 2002 displaced people were in fact built by the main religious jamaat of Ahmedabad. Along with providing relief, they 'encouraged a practice of Islam which focused on particular styles of worship, dress and everyday behaviour'. ${ }^{71}$ For Jasani, a by-product of the 2002 riots was that 'wearing an Islamic identity became inevitable' in Juhapura, which explains how a category as clear-cut as that of 'ghetto' entered the everyday vocabulary of both Hindu and Muslim residents of Ahmedabad. ${ }^{72}$ While residents of Juhapura-as well as of the other Muslim cities - felt increasingly and forcibly more isolated and marginalized, at the same time the open identification of such areas with Muslim ghettoes - or 'mini Pakistans' as they are labelled by Hindu fundamentalist groups and sympathizers - consolidated the perception of a divide and of Muslims as a consistent threat for a large proportion of the Hindu residents.

In this scenario, the way in which the AMC managed and controlled the entire area reveals how political decisions do contribute decisively to sharpening popular perceptions by determining the boundaries of what shall or shall not be considered a 'formal' city. Juhapura in fact had expanded largely outside the limits of the Municipal Corporation, but the latest expansion determined by the AMC in 2006 brought the entire area under municipal control. This did not mean a concurrent increase in the provision of infrastructure and public services such as

${ }^{70}$ It has been estimated that the population of Juhapura was less than Ioo, ooo but increased to more than 300,000 in the years following the riots. About the people displaced in the pogroms, see Citizens for Justice and Peace (ed.), Crime against Humanity. An Inquiry into the Carnage in Gujarat (Mumbai, 2002), Vol. III.

${ }^{71}$ Jasani, 'Violence, reconstruction and Islamic reform', p. 435.

${ }^{72}$ Ibid., p. 452; Jaffrelot and Thomas argued that as time passed, many instances of non-Islamic action emerged in the area, stressing education in particular as a means of upward mobility. Jaffrelot and Thomas, 'Facing ghettoisation in a riot city', pp. $74^{-76}$. 
schools, medical dispensaries, and hospitals, which were chronically lacking in the whole area. On the contrary, in the mid-2ooos AUDA and the AMC promoted the construction of a Bus Rapid Transport System (BRTS) to link the city centre to its peripheries: in a choice that can only appear deliberate, the new line was made to deviate from its route a few blocks from the 'entrance' to Juhapura and continue along a different road through the nearby Hindu-majority area of Vasna. ${ }^{73}$

The trajectory that led Juhapura from a well-planned model of a redevelopment colony to becoming a Muslim city is telling in terms of the various dynamics that interact in defining the boundaries between formality and informality, segregation and cultural exclusion, as well as between city and countryside. The contrast is striking between the new, fashionable high-rise buildings and the former colony-turned-slum of Shanklit Nagar, with the streets and walls acting as boundaries with respect to the rest of the city, as well as the fields and open lands that at the same time provide grazing lands for the latest cattle herders in the slums and financial opportunities for real estate developers.

\section{Conclusion: economic segregation meets religious fundamentalism}

I have witnessed all the fights that happened in the city, I saw them all since I was a kid when India and Pakistan happened [...]. In India, what did Gandhiji get in return for freedom? A bullet! The person who got you freedom, you shot him and the others are just enjoying and eating. This is what happened. [...] Then the Ayodhya case happened, then other and then other, just for the sake of chair. You are doing it just for the sake of chair otherwise nothing like this would have taken place.

But this all will continue and the one who has the stick, rules. But it is there, that because of Narendra Modi's entrance, the colour of Ahmedabad has changed. He has done hard work. The improvements that he has made, no other government has made such. If he stays for the next five years, he will improve it more [...]. Previously, the roads were so narrow that one truck would run on the road and the other on the service road; so he made it

${ }^{73}$ Janmarg BRTS - Ahmedabad Bus Rapid Transit System (Ahmedabad: Centre of Excellence in Urban Transport, CEPT University, 2008). The work of Nikita Sud, 'Constructing and contesting a Gujarati-Hindu ethno-religious identity through development programmes in an Indian province', Oxford Development Studies, vol. 35, no. 2, 2007, pp. I3 ${ }^{\mathrm{I}-\mathrm{I} 48 \text {, widely }}$ documents how at the state level, development programmes were used as a tool for further excluding Muslims, rather than providing them with an opportunity for economic upward mobility. 
double. In an area like Vastrapur it was all jungle, nobody dared to pass this jungle and today he has created a heaven there.

He is the only person who knows how to handle Gujarat. He wants to make Ahmedabad like Paris and he will definitely make it. He will definitely make it Paris! He brought it to this level so why would he not take it further? You can see the ten-storey building around, right.

When I am seeing the scenes of Paris in TV, I believe that he will make the same scene over here. For this I am telling you, that Muslims are still remembering Modi. $^{74}$

The 2002 anti-Muslim pogrom represented a peak in the trajectory of communal violence and discrimination in the country. For the city of Ahmedabad, the massive violence certainly contributed to marking urban internal boundaries more neatly, as well as to legitimizing a widespread intolerance towards the Muslim community.

As the largest recipient of people displaced during the pogroms and as the biggest Muslim area in the city, Juhapura represents a paradigmatic case to understand the various layers that produced extreme discrimination and, in fact, delegitimized members of this specific community as citizens. At a time when the Bharatiya Janata Party successfully managed to elevate development-oriented arguments to a hegemonic position within a debate over secularism and thus to propose the neo-liberal agenda as the sole possible solution to socio-economic as well as cultural inequalities in the country, the spatial definition of communal marginality has become even more evident. ${ }^{75}$

At the same time, the urban space began to embody the promise of development - or of an idea of development standardized over a stereotypical ideal of global cities, with the new Riverfront Development project putting Ahmedabad on the same level as 'Paris, or Melbourne'. So it does not surprise that an old resident of Shanklit Nagar projects his vision - or aspirations - for the future using the same imagery, no matter whether the project displaced some is,ooo families or that my

${ }^{74}$ Interview X, 76-year-old rickshaw driver, I6 July 2008, Shankalitnagar.

${ }^{75}$ In 2006, the Sachar Report on social and economic conditions of Indian Muslims focused great attention on the increasing levels of spatial, educational, and economic marginalization of Muslims across the country, highlighting how this critically affected their integration and possibilities for establishing inter-communal exchanges. Sachar, Social, Economic and Educational Status of the Muslim Community of India, pp. 242 ff. See also Sumit Ganguly, 'The crisis of Indian secularism', Fournal of Democracy, vol. I4, no. 4, 2003, pp. II-25; Tommaso Bobbio, 'Making Gujarat vibrant: Hindutva, development and the rise of subnationalism in India', Third World Quarterly, vol. 33, no. 4, April 2012, pp. $657-672$. 
interlocuter speaks from a shack on the external edge of the city, without a private water connection or a toilet. ${ }^{76}$ If development is the only road to secularism and equality, then the person who champions such an idea better than any other - Narendra Modi-is identified as the only one who can lead the state (and now the nation) out of economic backwardness. Ironically, during Modi's tenure as chief minister of Gujarat, while Ahmedabad was 'becoming like Paris', Juhapura progressively grew as a separate body within the main city. As a sub-city with its own services (schools, hospitals, water supply, etc.) and economic activities so as possibly to be less dependent on public services - which do not reach the area - it is a place where Muslims can evolve their 'survival mechanism in [such] a way that their interactions with the Hindu majority community gets minimized'. ${ }^{77}$

While narratives of exclusion and intolerance against members of the Muslim community consolidated in the years after the pogroms, urban policies exacerbated the exclusionary aspect of development by strengthening the equivalence between structural/spatial segregation of slums and moral/behavioural backwardness of their inhabitants. In line with this, the 2010 new Gujarat State Urban Slum Policy laid down such an equivalence from the very beginning. The first section, 'Governing principles', is centred on two main goals. First, this policy aims at 'integrating the slum dwellers into the mainstream of the society through up-gradation and/or relocation of all eligible slums and informal settlements $[\ldots]$ with due regard to the wider public interest'. Second, it seeks to prevent the 'proliferation of slums [...] by making available serviced and semi-serviced lands'. ${ }^{78}$ The trajectory from the I970s reveals much of the way in which the public authority modified its approach towards informal dwellings as well as practices. While the I970s approach considered slums to be an integral part of the city, they are now seen as something external to the 'mainstream of the society'.

\footnotetext{
${ }^{76}$ Sabarmati Riverfront Development Corporation (SRDG) (2012), available at http:// www.sabarmatiriverfront.com/, [accessed 5 February 202I]; Tana Trivedi et al., 'A study on socio-economic impact of Sabarmati Riverfront on life of displaced communities', Imperial Journal of Interdisciplinary Research, vol. 2, no. 7, 2016, pp. 1578-1602; Jalena Salmi, "“All the Others are Third-Class Citizens": Claiming Belonging, Countering Betrayal in World-Class Ahmedabad', presentation at the 9th Annual International Conference of the Asian Dynamic Initiative, University of Copenhagen, 26-28 June 2017.

${ }^{77}$ Mahadevia, 'A city with many borders', p. 26.

${ }^{78}$ Gujarat State Urban Slum Policy, Urban Development and Urban Housing Department, Government of Gujarat, 20I0, p. I [emphasis added].
} 
Moreover, slumdwellers are identified with the migrants, and they are 'largely responsible for the growth of slums and informal settlements in urban areas' and 'are perceived as a nuisance or the burden on the society'. ${ }^{79}$

The second goal of this policy guideline is equally significant: since relocation in case of eviction is granted by law, the principle is that of providing 'serviced and semi-serviced lands' to evicted residents. Historically, this always resulted in forms of displacement, as the 'lands' provided for compensation are more often than not plots outside the city, if not in the open countryside (in the jungle), without any given construction but with the possibility, more hypothetical than real, of being attached to public amenities like water, electricity, and sewerage, at the expense of the 'owner'. This principle is a reproduction, in drastically pejorative terms, of the Shanklit Nagar model. In that case, at least homes were built at the expense of the public authority with public funds, and people were relocated once the constructions werealmost - ready. Even so, as we have seen, the way people adapted was not as the AMC had foreseen: the sense of displacement and marginalization that led many people to abandon their homes and to recreate the slum on the riverfront boosted the emergence of an informal housing market in Shanklit Nagar.

Moreover, the 2010 policy document introduces a new aspect that further contributes to exacerbating the alienation of slums and slumdwellers from the spatial and sociocultural texture of the city. In contrast with the 1973 Slum Act, but in line with neo-liberal paradigms of urban development, the financial responsibility for implementing projects to renovate and improve slums is ideally shared with private institutions. Section 9 of the Gujarat State Urban Slum Policy is dedicated to specifying the share that several actors should bear to 'meet the costs of the projects' concerning slums. Along with urban local bodies, private sector institutions are in fact 'encouraged to join as a partner' in the improvement - or relocation - of slums, which is seen as an opportunity to 'commercially exploit' certain sections of urban territory. ${ }^{80}$ Reading between the lines of such policy documents allows us to understand what one of the older respondents of a riverfront slum identified as a sense of 'helplessness', where all aspects of life-from

${ }^{79}$ Ibid, p. I2.

${ }^{80}$ Ibid, p. 5 . 
work to housing to education - were at the mercy of unpredictable and arbitrary forces. $^{81}$

Despite evidence that the largest share of slumdwellers are long-term inhabitants of the city, public discourses and policy documents more or less explicitly reproduce the idea that slums are temporary settlements comprising semi-permanent structures. ${ }^{82}$ This adds to the construction of a culture of displacement, where marginal communities - and the Muslims as a preferred target in the era of Hindutva politics - are permanently kept in a subaltern position and reminded of their inevitable powerlessness before the public authority. As Derek Gregory pointed out in the case of the Israeli occupation of Palestine, playing with time is a key tool through which the powers-that-be reaffirm their arbitrariness: 'when everything is temporary almost anything - any crime, any form of violence - is acceptable'. ${ }^{83}$ The arbitrariness of a political power that uses urban planning tools to delegitimize and further marginalize entire communities within the urban space does provide a common terrain for understanding the mechanisms that contribute to link the production of residual spaces with the constant disempowerment of their inhabitants on a sociocultural level.

Partha Chatterjee observed that many of the interactions between political authorities and groups of marginal and informal dwellers move up and down the line separating legality and illegality, in a continuous dichotomy between recognition and invisibility. ${ }^{84}$ The trajectories of thousands of people who have lived all their lives in this grey zone of uncertain rules and arbitrary reactions may help us to understand that the quest for legitimacy, recognition, and to make the city a homely place is inscribed in the very history of India's urbanization. The history of

${ }^{81}$ Interview XXV, 73-year-old casual labourer, 5 December 2008, Shahpur (riverfront slum, demolished).

${ }^{82}$ Ahmedabad Slum Atlas, Vols I-IV (Ahmedabad: Cept University, 20I4).

${ }^{83}$ Derek Gregory, 'Palestine and the "War on Terror", Comparative Studies of South Asia, Africa and the Middle East, vol. 24, no. I, 2004, p. I9I. Recalling the Palestinian occupation may appear as an inflated comparison with the condition of Indian Muslims who, apart from Kashmir, are not suffering a regime of military occupation. However, as the recent approval of the Citizenship (Amendment) Act suggests, in its new configuration under the guidance of Narendra Modi and Amit Shah (who, it is necessary to highlight, were in charge of the Gujarat state government between 200I and 2014), the Indian government is largely using legislative tools to expel entire communities from accessing citizenship rights or from participating in the country's public life and spaces.

${ }^{84}$ Partha Chatterjee, The Politics of the Governed: Reflections on Popular Politics in Most of the World (New York: Columbia University Press, 2004), p. 40. 
Juhapura represents a paradigmatic example of how the management of an urban territory over a long period of time can contribute to drastically reducing the possibility of choice for people whose marginality does not depend exclusively on economic conditions, but is strictly intertwined with communal prejudices. With the rise to power of Hindu fundamentalist forces, religious and caste identities have become the measure that redefined residential patterns. In many Indian cities the presence of segregated community clusters is now a consolidated fact. Yet, at the same time, what made Juhapura a preferred destination for thousands of Muslims was not only rising intolerance and violence: the impossibility of conferring a rigid disciplinary effect to categories like housing illegality and informality kept this area in a grey zone where municipal control was selectively low. Thus it became a functional option for those people who were in search of a safe place, either to escape the risk of evictions - in the case of slumdwellers - or that of communal attacks - in the case of Muslims - or both. As Ghazala Jamil pointed out in her work on Muslim segregation in New Delhi, the idea of choice is an 'illusion'. 85 Similarly, in the memories of my respondents, 'choice' related to housing was subordinated to a sense of constraint and helplessness, while illegality and temporariness functioned as tools to reproduce territorial illegitimacy and delegitimize residents as citizens.

${ }^{85}$ Jamil, Accumulation by Segregation, p. 27. 